\title{
Gradients of disturbance to an algal canopy and the modification of an intertidal community
}

\author{
David R. Schiel* ${ }^{*}$ Stacie A. Lilley \\ Marine Ecology Research Group, School of Biological Sciences, University of Canterbury, Private Bag 4800, Christchurch, \\ New Zealand
}

\begin{abstract}
Disturbances over a range of intensities are common in intertidal communities, often causing partial removal of dominant species. However, most studies testing effects of disturbance on community structure use treatments where the dominant species is either present or absent, and usually record responses of only a few community components. Here, we test responses of the entire local community of benthic algae and invertebrates across a gradient of disturbance to a habitat dominant in southern New Zealand, the fucoid alga Hormosira banksii. Replicate $0.25 \mathrm{~m}^{2}$ plots of $100 \%$ cover of $H$. banksii were manipulated and maintained at $0,25,50$ and $75 \%$ cover at 2 sites for 13 mo. Throughout the experiment, communities in the complete removal and control plots were the most different from each other, but intermediate plots had varied responses and were usually not significantly different from each other. Generally, as cover of $H$. banksii decreased, community variability increased through time. Taxa richness declined with reduced $H$. banksii cover, with up to $77 \%$ of its variation explained by variation in canopy cover. Other fucoid algae declined across the gradient, with complete canopy removals having $92 \%$ less fucoid cover than control plots. Complete canopy removal had positive effects on ephemeral algae, especially at one site which exhibited large seasonal blooms. Bare space was greatest where canopies were completely removed and understory algae died. Diversity was greatest in plots with complete canopies rather than at intermediate levels, and there was no replacement of the dominant $H$. banksii by other species. There was no consistent effect on taxa across the gradient; some species responded linearly while others responded at threshold levels of canopy cover. This study shows the importance of disturbance gradients interacting with key species, which may have considerable bearing on reef community structure.
\end{abstract}

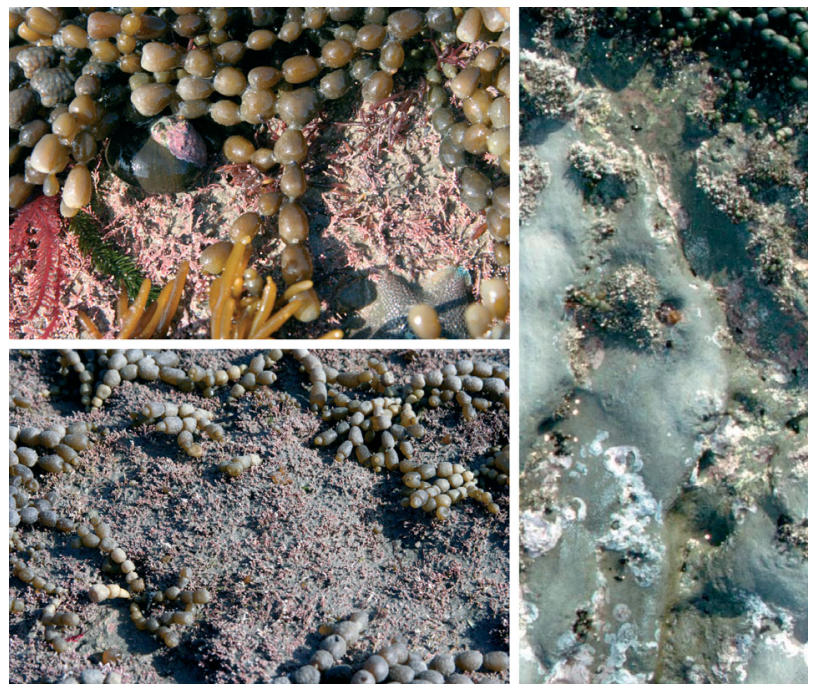

When algal canopies of Hormosira banksii (top left) are removed, this leads to nearly total loss of associated species (right); intermediate canopy losses (bottom left) result in species-specific density changes.

Photos: M. Hickford

KEY WORDS: Canopy • Disturbance - Gradient • Habitat-forming algae - Hormosira banksii · Positive interaction · Species removal $\cdot$ Threshold

$$
\begin{gathered}
\text { Resale or republication not permitted without } \\
\text { written consent of the publisher }
\end{gathered}
$$

\section{INTRODUCTION}

A change in the patterns of abundance of habitatforming species can have large effects on associated assemblages (Strauss 1991, Brown et al. 2001). For example, the removal of dense algal canopies (Dayton 1975, Bertness et al. 1999, Jenkins et al. 1999a), corals (Stimson 1985), seagrass (Ramage \& Schiel 1999), and mussels 
(Paine 1985, Seed 1996) can modify the local habitat, alter spatial complexity and affect surrounding understory benthic species, both positively and negatively.

In intertidal communities dominated by macroalgae, disturbances naturally occur over a wide gradient, from small impacts that remove a few individual plants, to large storms that can remove entire canopies (Underwood 1998, 1999). The consequent effects on assemblage structure across such disturbance gradients are variable. Typically, complete removal of a competitively dominant species allows other species to recruit into available space and grow, thereby increasing total benthic diversity, at least until the dominant becomes re-established (Connell \& Slayter 1977, Sousa 1979, Jenkins et al. 1999a, 2004). The loss of a dominant species can also lead to the loss of obligate understory species (Dayton 1975, Bertness et al. 1999, Jenkins et al. 2004, Lilley \& Schiel 2006) or lead to changes in direct and indirect interactions within a community (Underwood 1998, 1999). Smaller disturbances of algal canopies, however, provide only partial gaps of space and light for other species to recruit into, which may also lead to increased benthic diversity (Sousa 1979, Shea et al. 2004), but the effects of disturbances over a gradient from small to large are poorly documented in temperate marine communities.

Because natural populations of species are temporally and spatially variable, fluctuations in the abundance or canopy cover of dominant macroalgal species may not correspond linearly with their effects on the associated community (Strauss 1991, Brown et al. 2001, Speidel et al. 2001). One major hypothesis, the Intermediate Disturbance Hypothesis, predicts that diversity will be greatest at intermediate levels of disturbance and least when impacts are either small or very large (Connell 1978). Sousa (1979), for example, tested this for an intertidal algal assemblage on boulders in southern California and found that when the dominant red alga Gigartina canaliculata was removed, the community went through a period of high diversity before G. canaliculata returned to dominance. Increased diversity of benthic species was a consequence of the frequency and intensity of storm and wave disturbances to the community and the resulting likelihood of canopy loss. It is also possible that increasing disturbance intensity in communities dominated by algal canopies may result in a positive linear response of the associated assemblage through the greater provision of bare space and light gaps. Conversely, diversity could decline with increasing impacts if understory species rely on an established algal canopy during low tide to reduce temperature stress (Bertness et al. 1999, Lilley \& Schiel 2006) or solar radiation (Figueiredo et al. 2000). There may well be thresholds of responses that vary from species to species across a disturbance intensity gradient.
The relationships between the canopy cover of a habitat-dominating species and associated assemblages have some significance for understanding community structure and the impacts and recovery from disturbances in intertidal systems. Partial removal or thinning of macroalgal stands occurs frequently through anthropogenic disturbances, such as trampling (Brown \& Taylor 1999, Schiel \& Taylor 1999) or natural disturbances, such as wave action (Underwood 1998), 'burn-off' (i.e. destruction of parts of the organism from exposure-related stress) at low tide (Lilley \& Schiel 2006), and burial and abrasion by sediments (Airoldi \& Virgilo 1998, Schiel et al. 2006). Despite thinning occurring more frequently than complete removal of a stand (Strauss 1991), most experimental studies test canopy effects on communities by using treatments in which the dominant species is either present or absent, and typically focus on responses of a few components of interest in communities such as macroalgae and large molluscan grazers (Kennelly 1987, Bertness et al. 1999, Jenkins et al. 1999a,b, Speidel et al. 2001).

In southern New Zealand, moderately exposed rocky shores along much of the east coast are dominated by the fucoid alga Hormosira banksii (Turner) Decaisne. This species typically forms a dense canopy layer on the mid shore, with a standing biomass of up to $8 \mathrm{~kg} \mathrm{~m}^{-2}$. Plants have a very small discoid holdfast and are often removed by waves and storms (Underwood 1999) or human effects such as trampling (Schiel \& Taylor 1999). H. banksii is the only perennial, canopy-forming species able to survive in high abundance on the mid-shore (Schiel 2004). Lilley and Schiel (2006) showed that complete removal of $H$. banksii from $3 \times 3 \mathrm{~m}$ areas had strong negative effects on the local benthic community over 2 yr. Up to $45 \%$ of species in $H$. banksii beds were lost or greatly declined in abundance following the removal of $H$. banksii. These species included epifauna associated with $H$. banksii and understory species that could not survive on the mid shore without the protective canopy layer, such as other fucoids (e.g. Carpophyllum maschalocarpum and Cystophora spp.) and small, delicate branching algae (e.g. Chaetomorpha coliformis, Ceramium spp., Dictyota spp., and Laurencia thyrsifera). However, as in most other studies, gradients of disturbances were not examined.

Here, we examine how differences in the canopy cover of a habitat-dominating species affects the structure of the associated benthic community. We hypothesized that increasing levels of disturbance to a macroalgal canopy would result in greater cover of opportunistic ephemeral algae, greater recruitment of less competitive perennial species, more grazers and a loss of obligate benthic understory species. 


\section{MATERIALS AND METHODS}

In January 2003, fifteen $0.5 \times 0.5 \mathrm{~m}$ plots were marked in the mid-littoral zone $(0.85$ to $1.0 \mathrm{~m}$ above lowest astronomical tide level, LAT), over a $30 \mathrm{~m}^{2}$ area on each of 2 rocky reef sites (Mudstone Bay and Wairepo Flats) on the Kaikoura Peninsula $\left(42^{\circ} 25^{\prime} \mathrm{S}\right.$, $\left.173^{\circ} 41^{\prime} \mathrm{E}\right)$. Both reefs extend ca. $150 \mathrm{~m}$ from the upper intertidal to the subtidal zones, but are generally protected from severe wave action by offshore reefs and a coastal topography that deflects swells (Ramage \& Schiel 1999). The mid-intertidal zone at both sites is covered with a dense canopy (typically 95 to $100 \%$ cover) of the fucoid alga Hormosira banksii. Plants of this species can reach up to ca. $35 \mathrm{~cm}$ in length in these habitats, are often densely packed and fused at the holdfast, and can be difficult to distinguish as individuals. To create consistent treatments, therefore, we used the percentage cover of canopy as the main factor to manipulate. Canopy treatments were: $0 \%$ complete removal (T0), $25 \%$ intact (T25), 50\% intact (T50), $75 \%$ intact (T75) and unmanipulated controls (T100). Three replicates of each of the 5 treatments were randomly assigned to the pre-marked plots. To thin treatment plots, plants were removed haphazardly throughout a plot to avoid clumping of plants. Plants were removed at the holdfast with a knife to avoid damaging the understory and substratum. All plants overhanging the removal plots from outside were trimmed back to eliminate possible edge effects of the canopy. Treatments were initiated as plants lay over the reef at low tide; all plots were then visually re-checked using a quadrat on 2 subsequent tides to ensure that the initial treatment covers were consistently achieved. Plots were maintained at their treatment levels of canopy cover throughout the experiment because the primary factor of interest was canopy cover. A $0.25 \mathrm{~m}^{2}$ strung quadrat was used to monitor the benthic community prior to removal and at 1, 4, 7, 10 and 13 mo after initial removal. Percentage cover estimates were made for all algae and sessile invertebrates, and mobile invertebrates were counted. Layering of species often resulted in $>100 \%$ total cover of all algae. All benthic taxa larger than ca. $3 \mathrm{~mm}$ were included. To avoid destructive sampling of the understory, identification of all species was done in the field. Most organisms were identified to the species level, but many smaller algae could be identified only to genus; many of the smaller invertebrates (especially polychaetes and isopods) were identified by family (see Appendix 1).

Multivariate and univariate analyses were used. Non-metric multidimensional scaling (nMDS) using Bray-Curtis distances on 4th-root transformed data was used to visualise changes in the understory com- munity across the disturbance gradient. Analysis of similarity (ANOSIM) was used to test for differences in community composition across sites, between treatments within sites, and through time. Where global R-statistics were statistically significant, pairwise ANOSIM tests were used to examine treatment differences. Because of the loss of power in pairwise tests, pvalues were often not significant, and the R-value was used as an indicator of relative dissimilarity between treatments (Clarke 1993). Similarity of percentage (SIMPER) was used to demonstrate which species, or groups of species, were responsible for any patterns found between treatments and an index of multivariate dispersion (IMD) was calculated to compare the variability of communities across treatments through time (Clarke 1993, Clarke \& Warwick 2001) using Primer v5.1.2 (Clarke \& Gorley 2001). See Clarke (1993) for further discussion of the analyses used here.

Univariate analyses (repeated measures general linear models) were performed on the richness and abundance of specific groups of taxa. A repeated measures model was used to account for the variability through time of all treatments. However, it is noted that limitations can occur due to non-independence through time. We also used regression analyses to test for responses of variables to the disturbance gradient, on data from the last sampling date. Homogeneity of variances was tested by Cochran's $C$-test and, where necessary, percentage cover data were square-root arcsine transformed and counts of individuals were square-root transformed to fulfill the assumptions of ANOVA. Fisher's least significant difference (LSD) post-hoc analysis was used to examine differences within factors.

\section{RESULTS}

Prior to removal, Hormosira banksii cover was between 95 and $100 \%$ at both sites. The cover of $H$. banksii in the control plots did not vary from this over the study period. Taxa richness per $0.25 \mathrm{~m}^{2}$ plot across all treatments ranged from 10 to 31 , with a total of 71 taxa found at Mudstone Bay and 58 taxa at Wairepo Flats throughout the duration of the experiment (see Appendix 1). The distribution of species abundances was heavily skewed with only $2.4 \%$ (Mudstone Bay) and $4.5 \%$ (Wairepo Flats) of all taxa having $>5 \%$ cover or 5 ind. plot $^{-1}$. Taxa with cover consistently greater than $5 \%$ were Cystophora torulosa, Corallina officinalis and nongeniculate corallines; the most abundant invertebrates were Turbo smaragdus, Maorichiton caelatus and Chiton pelliserpentis. The great majority of other species had $<1 \%$ cover or $<1$ ind. plot $^{-1}$. 
There were initial differences in the community composition of the 2 sites prior to the start of the experiment (ANOSIM; R $=0.55, \mathrm{p}<0.001$ ). These differences were primarily due to greater richness and abundance of molluscan macrograzers (>5 mm shell length), especially Cantharidella tesselata, Chiton pelliserpentis, Maorichiton caelatus, Melagraphia aethiops, and Turbo smaragdus at Wairepo Flats; and greater richness and abundance of red algal species, particularly Champia novae-zelandiae, Dipterosiphonia heteroclada, Gigartina chapmanii, and Polysiphonia decipiens at Mudstone Bay. Because of these initial site differences, treatments were analysed separately for each site.

\section{Community-wide effects}

The canopy thinning treatments produced generally similar responses of the communities at both sites (Table 1). Over the entire 13 mo of the experiment, using combined data from all monitoring times, there was a gradient of community composition across the treatments. At Mudstone Bay, the complete canopy removals (T0) and controls (T100) were significantly different from each other and from all other treatments. The intermediate disturbance treatments (T25, T50, T75) had similar community composition over the course of the study, and the T75 and T100 treatments were also similar. At Wairepo Flats, there was a broad overlap across the treatments. T0 was significantly different from T75 and T100, T100 was different from all others except $\mathrm{T} 75$, and the 4 non-control treatments broadly overlapped in their community responses. Therefore, plots with full canopies and absent canopies
Table 1. Pairwise Analysis of Similarity (ANOSIM) between the canopy thinning treatments, combining all data over the 13 mo of monitoring. Significant p-values are in bold. Global R-statistics-Mudstone Bay: $\mathrm{R}=0.35, \mathrm{p}<0.001$; Wairepo Flats: $\mathrm{R}=0.22, \mathrm{p}<0.001$. Under the table is a representation of similar treatments based on the pairwise tests. Treatments connected by lines are not significantly different

\begin{tabular}{|c|c|c|c|c|c|}
\hline \multirow[t]{2}{*}{ Treatment } & \multicolumn{2}{|c|}{ Mudstone Bay } & & \multicolumn{2}{|c|}{ Wairepo Flats } \\
\hline & $\mathrm{R}$ & $\mathrm{p}$ & & $\mathrm{R}$ & $\mathrm{p}$ \\
\hline T0 vs. T25 & 0.259 & $<0.001$ & & 0.090 & 0.03 \\
\hline T0 vs. T50 & 0.312 & $<0.001$ & & 0.088 & 0.03 \\
\hline T0 vs. T75 & 0.342 & $<0.001$ & & 0.218 & $<0.001$ \\
\hline T0 vs. T100 & 0.630 & $<0.001$ & & 0.542 & $<0.001$ \\
\hline T25 vs. T50 & 0.004 & 0.38 & & 0.061 & 0.08 \\
\hline T25 vs. T75 & 0.024 & 0.22 & & 0.072 & 0.05 \\
\hline T25 vs. T100 & 0.296 & $<0.001$ & & 0.321 & $<0.001$ \\
\hline T50 vs. T75 & 0.077 & 0.04 & & 0.127 & 0.06 \\
\hline T50 vs. T100 & 0.328 & $<0.001$ & & 0.375 & $<0.001$ \\
\hline T75 vs. T100 & 0.127 & 0.06 & & 0.081 & 0.04 \\
\hline \multicolumn{6}{|l|}{ Mudstone Bay } \\
\hline Treatments & T0 & $\mathrm{T} 25$ & T50 & $\mathrm{T} 75$ & T100 \\
\hline Wairepo Flats & & & & & \\
\hline
\end{tabular}

tended to be different from each other and from most of the intermediate canopies, which themselves formed similar communities.

Differences in community composition after 13 mo were evident in the nMDS plots of treatments at each site (Fig. 1A,B). At both sites, the complete canopy removal and control plots formed distinct clusters, whereas the other treatments were interspersed in multivariate space. The tighter cluster of the 3 intermediate treatments at Mudstone Bay indicates their greater similarity of community responses than at Wairepo Flats.
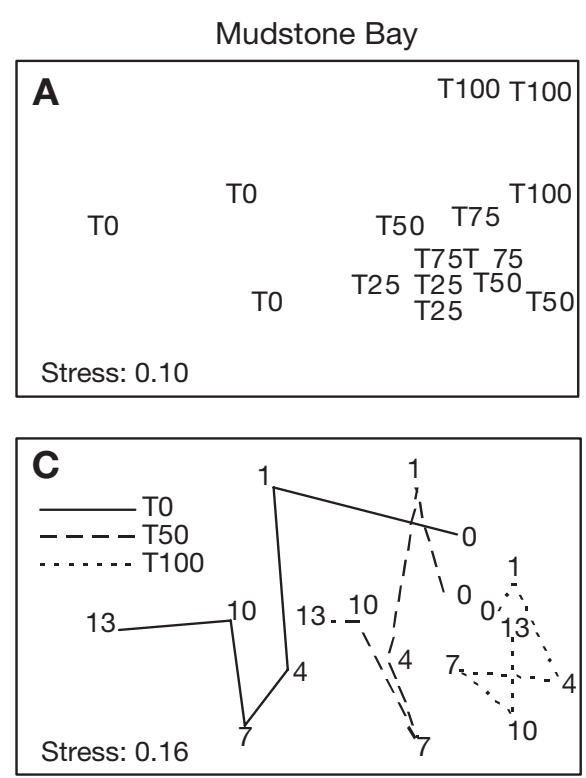
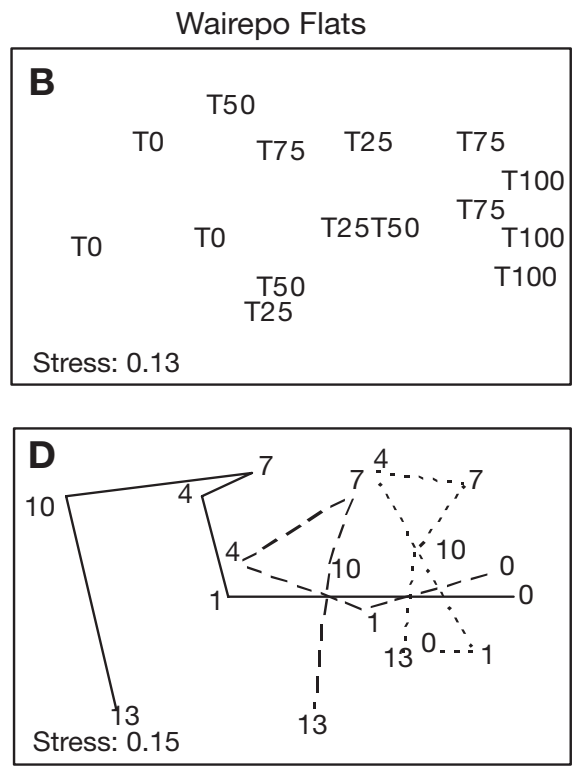

Fig. 1. 2-dimensional non-metric multidimensional scaling (nMDS) plots showing $(\mathrm{A}, \mathrm{B})$ differences in community composition for $\mathrm{T} 0$, T25, T50, T75 and T100 Hormosira banksii thinning treatments $13 \mathrm{mo}$ after experimental initiation at (A) Mudstone Bay and (B) Wairepo Flats; and the temporal variation in the T0, T50 and T100 treatments at (C) Mudstone Bay and (D) Wairepo Flats (each numeral represents the month following initial removal) 
The time trajectories of community responses among the treatments can be visualised in the nMDS plots (Fig. 1C,D). In both sites, the community composition in the complete canopy removal treatment (T0) quickly diverged from the other treatments in multivariate space. Controls showed little variation over time at Mudstone Bay, but at both sites the end points for controls were remarkably similar to the starting points (seen as the positions of 0 and 13 relative to each other for the T100 lines). The intermediate treatment T50 clearly produced an intermediate response in community development. The 2 other intermediate treatments (T25 and T75) did not significantly differ from T50 (Table 1), so were excluded to improve clarity of graphs.

In addition to a gradient of community development, there was a gradient in the variability of responses over 13 mo (Table 2). The IMD values at Mudstone Bay declined linearly from the complete removal plots (T0) to the control plots (T100), indicating more variability through time with increasing levels of disturbance to the canopy. The IMD values were more variable among disturbance treatments at Wairepo Flats, but the controls with a full canopy were the least variable of all treatments.

The species that accounted for differences among treatments tended to be similar between the sites. At both sites, SIMPER identified the control plots (T100) as having more molluscan macrograzers (particularly the chitons Chiton pelliserpentis and Maorichiton caelatus) and perennial fucoid algal cover (Carpophyllum maschalocarpum, Cystophora scalaris and Cystophora torulosa) than the other treatments. Plots with complete canopy removal (T0) had more ephemeral algae (especially Adenocystis utricularis, Colpomenia sinuosa, Leathesia difformis and Ulva/Enteromorpha complex) than the T25-T100 plots. At Wairepo Flats, the predatory gastropod Haustrum haustorium, the crabs Halicarcinus cookii and Halicarcinus varius and the sea star Patiriella regularis were all less abundant in T0, T25 and T50 compared to the T75 and T100 plots.

Table 2. Index of multivariate dispersion (IMD) values of each canopy thinning treatment showing the relative variability between disturbance treatments 13 mo after initiation at Mudstone Bay and Wairepo Flats

\begin{tabular}{lcc|} 
Treatment & \multicolumn{2}{c|}{ IMD value } \\
& Mudstone Bay & Wairepo Flats \\
\hline T0 & 1.35 & 1.08 \\
T25 & 1.07 & 1.13 \\
T50 & 0.94 & 0.94 \\
T75 & 0.78 & 1.05 \\
T100 & 0.57 & 0.81 \\
\hline
\end{tabular}

\section{Taxon-specific responses through time}

The taxa richness of communities in the disturbance treatments varied significantly by site and treatment (Table 3). The number of taxa in treatments fluctuated considerably through time (Fig. 2A,B). There was an initial decrease in the number of taxa in most removal treatments at both sites. The intensity of this response increased with increasing levels of disturbance and was particularly evident in the T0 plots. Repeated measures analysis of variance and Fisher's LSD post-hoc tests showed that complete removal plots (T0) generally had significantly fewer taxa than all other treatments, and T100 plots had significantly more taxa than all other treatments at both sites. The treatments T25, T50 and T75 were positioned mostly in step-wise fashion between T0 and T100. There was a significant Treatment $\times$ Time interaction, with taxa richness steadily increasing in T100, while T0 declined after winter at Mudstone Bay and during summer at Wairepo Flats. In the T0, T25 and T50 treatments at both sites, there was a tendency for taxa richness to be greatest during the intermediate period of 4-10 mo. This was largely a reflection of an increase in ephemeral algal species which tend to bloom during the winter-spring months (see paragraph below). Control plots, however, generally increased in richness through time.

Algal species were grouped into ephemerals and perennials. The most abundant ephemeral species were the browns Colpomenia sinuosa and Ectocarpus spp. and a green Ulva/Entermorpha complex. Mudstone Bay had significantly greater ephemeral cover than Wairepo Flats, but this varied by treatment (Table 3). The significant effects of treatment, Site $\times$ Treatment, and Time $\times$ Site $\times$ Treatment were all driven by the increased cover in complete removal plots (T0) during late winter ( 7 mo after removal) at Mudstone Bay (Fig. 2C,D). The treatments at Wairepo Flats were similar through time; the cover of ephemeral algae showed only a slight increase midway through the study. Overall, there was no evidence of a gradient of response to the disturbance levels. Complete removal of the canopy was necessary for a bloom to occur.

Fucoid algal cover, excluding Hormosira banksii, was comprised of Carpophyllum maschalocarpum, Cystophora retroflexa, Cystophora scalaris and Cystophora torulosa. Their cover varied significantly among treatments which had varying effects through time (Table 3). Overall, sites were not significantly different. As for previous groupings, the T0 and T100 treatments tended to be separate from all others, with T0 plots showing the greatest decrease in fucoids as they burned off after the canopy was removed, and T100 plots showing an increase as fucoids (especially $C$. 


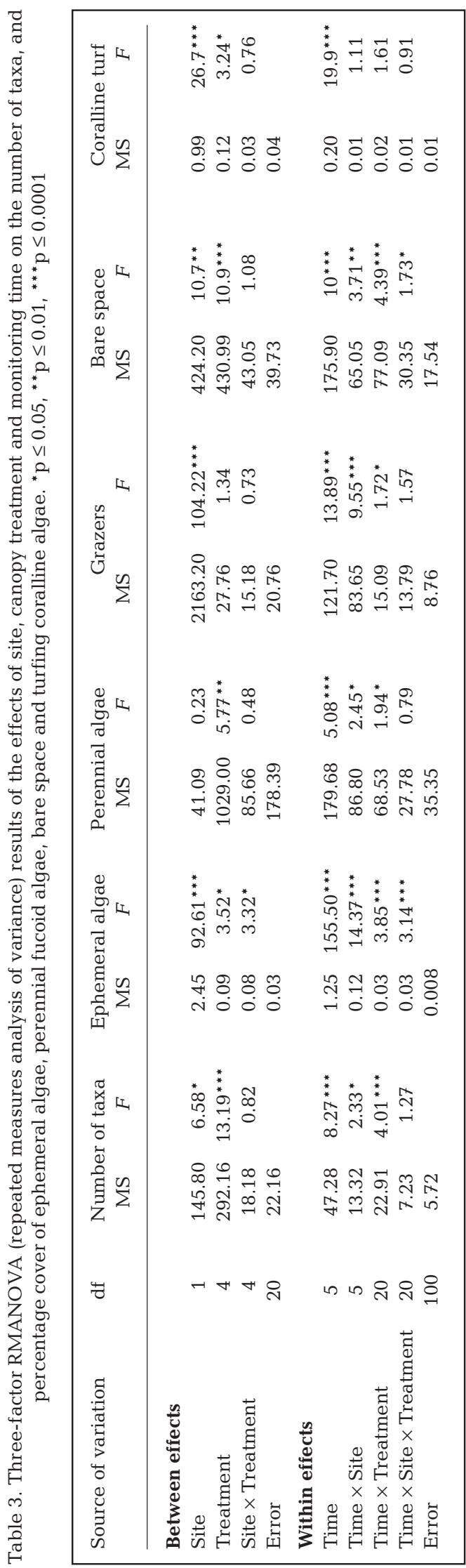
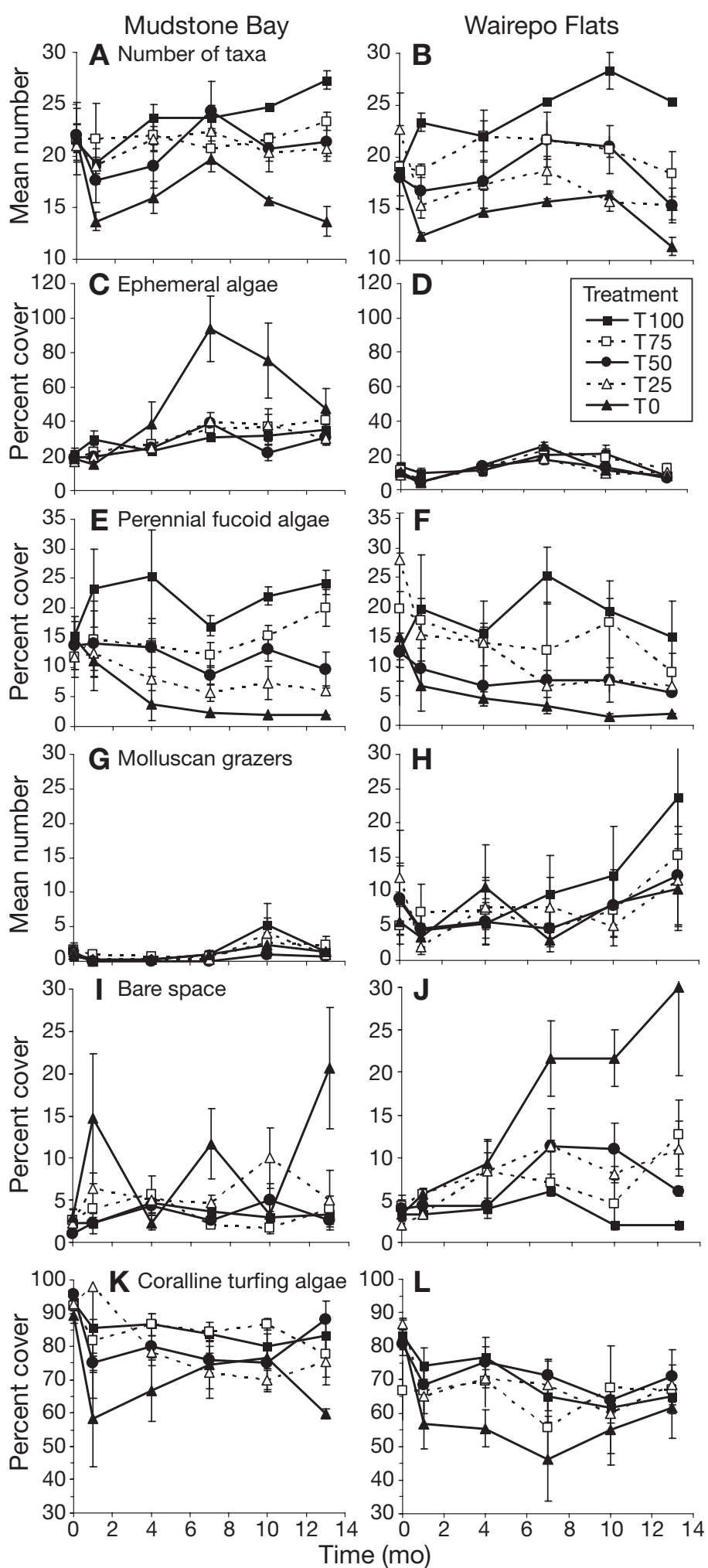

Fig. 2. Temporal variation in: $(A, B)$ the number of taxa, $(C, D)$ percentage cover of ephemeral algae; $(\mathrm{E}, \mathrm{F})$ percentage cover of perennial fucoid algae, $(\mathrm{G}, \mathrm{H})$ number of molluscan grazers, $(\mathrm{I}, \mathrm{J})$ percentage cover of bare space, and $(K, L)$ coralline turfing algae in the 5 Hormosira banksii partial removal treatments, at Mudstone Bay and Wairepo Flats. Values are mean $( \pm \mathrm{SE})$ 
torulosa) recruited beneath the canopy (Fig. 2E,F). The partial removal treatments generally responded in a step-wise fashion, although the T25 and T50 plots grouped together at Wairepo Flats throughout most of the study.

The different treatments produced no overall effect on grazers, but Wairepo Flats had more grazers than Mudstone Bay (Table 3, Fig. 2G,H). The most common molluscan grazers at both sites were Chiton pelliserpentis, Maorichiton caelatus and Turbo smaragdus. At Wairepo Flats, increased numbers of grazers after 10 mo in all treatments, particularly the control plots, were due to recruitment of Cantharidella tesselata, M. caelatus and T. smaragdus.

Primary space was mostly bare rock or covered by geniculate coralline algae (Corallina officinalis and Jania sp.) and nongeniculate coralline algae. Bare space varied significantly by treatment and site, but there were no consistent effects through time across the treatments and sites (Table 3). The complete removal plots had the most bare space throughout most of the study at both sites, and the controls the least (Fig. 2I,J). Post-hoc tests showed that the T25 plots had significantly more bare space than controls (T100) at both sites. C. officinalis was the most abundant of the coralline species. Its cover varied among treatments, sites and through time (Table 3). Within one month of treatment initiation, the coralline cover decreased in all treatments at both sites, but the effect was especially great in the T0 plots where it decreased by 25 to $30 \%$ as burnoff occurred (Fig. 2K,L). All other treatments fluctuated through time with no clear pattern.

\section{Responses after 13 mo}

Regression analyses were used to test for trends in response variables over the disturbance gradient at the end of our experiment. The average number of taxa had a highly significant response across the canopy levels of Hormosira at both sites (Fig. 3A). Between 72 (Mudstone Bay) and $77 \%$ (Wairepo Flats) of the variation in taxa numbers was explained by the treatment levels. The slopes were the same for both sites $(b=0.12)$ but there were more species across all treatments at Mudstone Bay. Ephemeral algae showed no significant trend across treatments at either site (Fig. 3B). Neither slope was significant, but there was far greater ephemeral cover overall at Mudstone Bay (mean = $36.9 \%$ ) than at Wairepo Flats (mean $=8.9 \%$ ). Fucoid cover showed significant responses at both sites, but the magnitude of the response was less at Wairepo Flats than at Mudstone Bay (test of slopes: $F_{1,26}=6.4, \mathrm{p}=0.017$ ). Less of the variation in fucoid cover was accounted for by the treatments at Wairepo Flats $\left(\mathrm{R}^{2}=86 \%\right.$ at Mudstone Bay, $38 \%$ at Wairepo Flats). At both sites, however, there was generally a step-wise increase in fucoid cover with increasing cover of the Hormosira canopy.
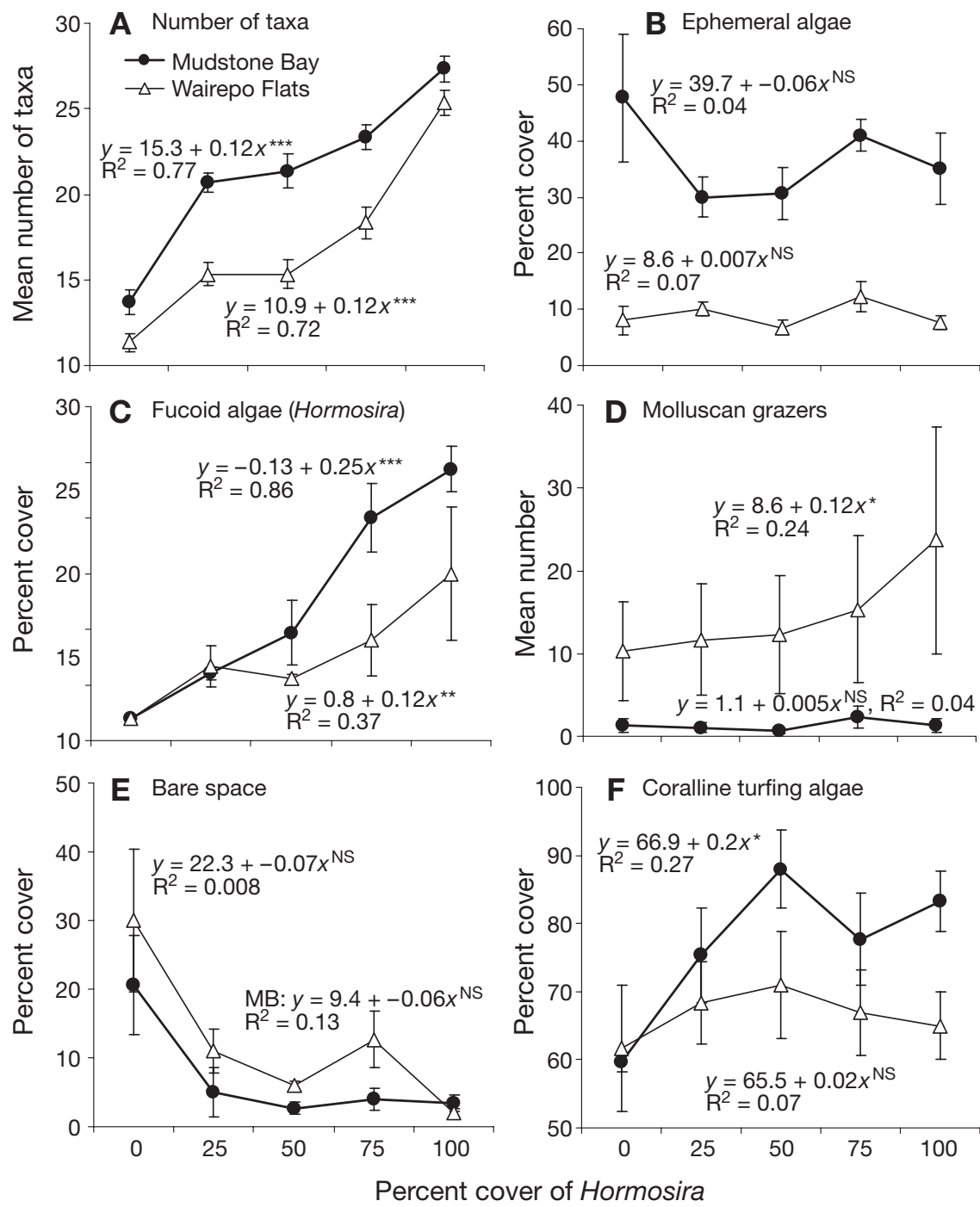

Fig. 3. (A) Number of taxa; (B) abundance of ephemeral algae; (C) abundance of perennial fucoid algae, excluding Hormosira banksii; (D) number of molluscan grazers; (E) percentage cover of bare space; and $(F)$ percentage cover of coralline turfing algae, in the Hormosira banksii partial removal treatments (all treatments combined) 13 mo after experiment initiation at Mudstone Bay and Wairepo Flats. Values are mean $( \pm \mathrm{SE})$. Regression equations and $\mathrm{R}^{2}$ values for each trajectory are shown. ns: not significant, ${ }^{*} \mathrm{p} \leq 0.05,{ }^{* *} \mathrm{p} \leq 0.01,{ }^{* * *} \mathrm{p} \leq 0.0001$ 
Molluscan grazers showed a positive response to canopy cover at Wairepo Flats but not at Mudstone Bay (Fig. 3D), but the variation was high and little of it was accounted for by the treatment levels $\left(\mathrm{R}^{2}=24 \%\right.$ at Wairepo Flats). Across all treatments there were far more grazers at Wairepo Flats (mean $=14.7$ ) than at Mudstone Bay (mean = 1.3).

Bare space was highly variable, particularly in the T0 treatments, and there was no significant trend across the treatments at either site (Fig. 3E). Over all treatments, there was more bare space at Wairepo Flats $($ mean $=18.6 \%)$ than at Mudstone Bay $($ mean $=6.5 \%)$. Turf-forming coralline algae increased significantly across the disturbance gradient at Mudstone Bay to T50 but not at Wairepo Flats (Fig. 3F). The significant effect was due mostly to the reduced cover of corallines in the T0 treatment. Over all treatments, there was a greater cover of corallines at Mudstone Bay (mean = 76.8\%) than at Wairepo Flats $($ mean $=66.6 \%)$.

\section{DISCUSSION}

Our study showed that thinning of a canopy of a dominant fucoid alga produced variable responses on associated species, and that these varied between sites. After 13 mo over a gradient of canopy cover, the number of taxa and the perennial fucoid cover (other than the original dominant) decreased across the disturbance gradient from a full Hormosira banksii canopy to complete canopy removal. Ephemeral algae bloomed in complete removal plots of one site and, perhaps surprisingly, primary bare space increased only in complete removal plots. These responses varied throughout the 13 mo of the study. In no treatments or individual plots, however, did another species establish dominance. This is consistent with longer term community effects of canopy removals on these shores (Lilley \& Schiel 2006, Schiel 2006).

At different times of the year there was no significant difference between the 3 intermediate treatments in the multivariate responses. The structural changes in the community were driven more by the addition or loss of understory species than by changes in their abundances. The intermediate response of partial removal of Hormosira banksii on the understory was evident in the responses of specific groups of taxa. Fucoid algae, the largest of the space-occupiers with the greatest biomass on these shores (Schiel 2006), varied by treatment. Carpophyllum maschalocarpum, Cystophora scalaris and Cystophora torulosa are lowshore species, and seem capable of surviving in the mid-shore region only under a dense protective layer of $H$. banksii, which reduces heat and temperature stress during emersion (Lilley \& Schiel 2006). In con- trast to other studies in which a dominant canopy was removed (Jenkins et al. 2004) there was no replacement of $H$. banksii by any other fucoid. There are at least 4 other fucoid species that occur within several metres of $H$. banksii at the study sites, yet none of these can survive alone over most of the tidal range inhabited by $H$. banksii (Schiel 2006).

Ephemeral algae often bloom following disturbances (Connell 1972, Sousa 1979, Farrell 1991, BenedettiCecchi \& Cinelli 1992a), but this was highly variable in our study. The opportunistic species Colpomenia sinuosa, Ectocarpus spp., Leathesia difformis and an Ulva/ Enteromorpha complex at Mudstone Bay bloomed following complete canopy removal. This bloom was seasonal and died off during late spring. There were clear site-related differences. Mudstone Bay, which is suspected of having a higher nutrient load because of riverine input and the large number of fur seals present, had greater cover of ephemeral algae than Wairepo Flats, which had no treatment effect. It appears, therefore, that the response of ephemeral algae relies on a combination of canopy removal, the provision of bare space and specific site characteristics relating to productivity (cf. Foster et al. 2003).

Studies elsewhere have shown that ephemeral algae can delay the development of a perennial community through the pre-emption of space during critical times of the year when other species could recruit (Lubchenco \& Menge 1978, Sousa 1979, Coleman 2003, Foster et al. 2003). In our study, however, it appears that the main mechanism limiting the richness and abundance of understory fucoids is not competitive effects between algal species, but the lack of a dense algal canopy (see also Lilley \& Schiel 2006), outside of which perennial low-shore species and smaller finely branching algal species are unable to survive. There was no evidence of competitive effects between algal species. The only treatment that had a great influx of ephemerals (T0 at Mudstone Bay) had an almost identical response in fucoid recruitment as the other treatments in which few ephemerals were present. Ephemeral algae, therefore, do not seem to be a key component in the recruitment of longer-lived species in the community in these mid-shore regions.

There was no effect of canopy thinning on the abundance of molluscan macrograzers, which commonly increase in abundance following complete removal of macroalgae (Connell 1972, Jenkins et al. 1999a,b, 2004). For example, Jenkins et al. (1999a,b, 2004) found that an influx of limpets following the removal of an Ascophyllum canopy persisted over 12 yr. On the shores near Sydney, Australia, Underwood $(1998,1999)$ found that grazing and predatory relationships were altered after removal of Hormosira canopies. Following large-scale removal of $H$. banksii, whelks de- 
creased in abundance leading to an increase in the abundance of barnacles, which affected the recovery of $H$. banksii. There was little evidence of these types of responses in our study. There were few predatory whelks and the majority of grazing species found at Wairepo Flats and Mudstone Bay (e.g. Chiton pelliserpentis, Maorichiton caelatus and Turbo smaragdus) tend to reside in small cracks. Habitat heterogeneity in the form of surface rugosity may be more important to these species than the presence of an overlying algal canopy. Furthermore, the dominant grazer of this zone, the turbinid gastropod Turbo smaragdus, has little effect on fucoid recruitment, although it may affect ephemeral algae (Schiel 2006).

Several studies in subtidal habitats and tide pools have documented an inverse relationship between the cover of turfing algae (particularly coralline algae) and canopy cover; when canopies are removed, turfing algae tend to increase (Benedetti-Cecchi \& Cinelli 1992b, Melville \& Connell 2001). However, we found a clear reduction in the percentage cover of Corallina officinalis following complete removal of the canopy. The principal mechanism underlying this decline may be the increase in light and temperature following the canopy removal. A high proportion of $C$. officinalis became bleached white and then died off. The dieback of coralline algae corresponded to the increase (and associated variability) in bare space. Intermediate densities of Hormosira banksii had an intermediate level of bare space between controls and complete removal. This bare space was not colonised except for the bloom of ephemeral Ulva/Enteromorpha species during spring at Mudstone Bay, illustrating the functional importance $H$. banksii in the community as the only large, perennial canopy-forming species able to survive throughout the mid shore.

There have been only a few other studies in the marine environment that have examined the effects of partial canopy removal on the understory. Kennelly (1987) reduced the cover of the subtidal kelp Ecklonia radiata in Australia by removing various sections of the plants (fronds, fronds plus stipe and complete plants). The partial removal treatments had similar effects to complete removal, with an increase in turfing algae and a decrease in encrusting algae. This effect was due to the die-off of damaged plants in the partial canopy treatments. Speidel et al. (2001) manipulated the canopy of the intertidal fucoid Fucus gardneri to $20,40,60,80$ and $100 \%$ cover, and examined the effects on the number of germlings, recovery of adult plants, grazing molluscs and ulvoid cover. Similar to our study, a reduction in the $F$. gardneri canopy resulted in no effect on molluscan macrograzers. $F$. gardneri recovery showed a non-linear response to partial removal of the adult canopy. Removal of all plants set recovery back by several months, but if some plants remained (20 to $80 \%$ cover), recruitment and recovery occurred at a faster rate (Speidel et al. 2001). In our study, there was a significant linear response in fucoid algae and the number of taxa to disturbance levels (Fig. 3). However, multivariate analyses showed non-linear effects across the entire community, with the 3 intermediate levels having a similar response that was intermediate between the 0 and $100 \%$ levels of disturbance. Therefore, there appears to be 2 thresholds of responses of the community to disturbance.

Much research has been done on how variability in size (Farrell 1989, Kim \& DeWreede 1996), frequency (Sousa 1979) and intensity (Schiel \& Taylor 1999, Speidel et al. 2001) of disturbance affects communities. According to the non-equilibrium disturbance paradigm, the removal of a dominant species can prevent the monopolisation of limiting resources by a small number of species (Connell \& Slayter 1977, Sousa 1979, Benedetti-Cecchi \& Cinelli 1992a,b). The intermediate disturbance hypothesis predicts that maximum diversity should occur at intermediate intensities of disturbance (Connell 1978), although these intermediate responses are known to be complex and variable (Johst \& Huth 2005). Consistent with this model, highest diversity in our experiment should have occurred with a $50 \%$ reduction of canopy cover, which left some plants laying over the substratum during periods of emersion and sheltering those species in the understory, while still providing space for new species to colonise. However, with taxa richness as a proxy for diversity, there was no 'intermediate disturbance' response. We found that the greatest diversity occurred in the unmanipulated control plots and, at the end of the experiment, there was a significant decrease in diversity with increasing levels of disturbance (Fig. 3). It appears in this system, therefore, that the dominance of a single species has mostly a positive effect on the local benthic community. In contrast to other studies in which the partial removal or thinning of a dominant species resulted in the creation of a mixed species matrix (Sousa 1979), on the southern shores of New Zealand it mostly results in a decline in taxa richness and changes in the composition of the surrounding community. Positive effects on a wide range of species from habitat modification by a dominant species clearly has a major influence on diversity and community structure (cf. Bertness et al. 1999, Bruno \& Bertness 2001). Furthermore, the dominant species is resistant to invasion and replacement by other species. There are no large perennial, canopyforming species that are physiologically capable of invading these areas. Hormosira banksii is a key species that is crucial to the overall diversity and maintenance of community structure on these shores. In other 
such situations, with one or few dominant species and weak trophic interactions, it is likely that these sorts of positive interactions on associated species will be important to community processes and structure. Future studies could investigate how these may be altered by varying levels of disturbance and the extent to which there are gradient or threshold responses.

Acknowledgements. We thank R. Dunmore and S. Wood for help in the field, the Marine Ecology Research Group (especially Drs. D. Taylor and M. Hickford) and 4 anonymous reviewers for their helpful comments on this manuscript. We also thank J. van Berkel and the University of Canterbury for providing laboratory facilities at Kaikoura, the Andrew W. Mellon Foundation of New York and the New Zealand Foundation for Research, Science and Technology for funding throughout the duration of this study.

\section{LITERATURE CITED}

Airoldi L, Virgilo M (1998) Responses of turf-forming algae to spatial variations in the deposition of sediments. Mar Ecol Prog Ser 165:271-282

Benedetti-Cecchi L, Cinelli F (1992a) Effects of canopy cover, herbivores and substratum type on patterns of Cystoseira spp. settlement and recruitment in littoral rockpools. Mar Ecol Prog Ser 90:183-191

Benedetti-Cecchi L, Cinelli F (1992b) Canopy removal experiments in Cystoseira-dominated rockpools from the Western coast of the Mediterranean (Ligurian Sea). J Exp Mar Biol Ecol 155:69-83

Bertness MD, Leonard GH, Levine JM, Schmidt PR, Ingraham AO (1999) Testing the relative contribution of positive and negative interactions in rocky intertidal communities. Ecology 80:2711-2726

Brown JH, Ernest SKM, Parody JM, Haskell JP (2001) Regulation of diversity: maintenance of species richness in changing environments. Oecologia 126:321-332

Brown PJ, Taylor RB (1999) Effects of trampling by humans on animals inhabiting coralline algal turf in the rocky intertidal. J Exp Mar Biol Ecol 235:45-53

Bruno JF, Bertness MD (2001) Habitat modification and facilitation in benthic marine communities. In: Bertness MD, Gaines SD, Hay ME (eds) Marine community ecology. Sinauer Associates, Sunderland, MA

Clarke KR (1993) Non-parametric multivariate analyses of changes in community structure. Aust J Ecol 18:117-143

Clarke KR, Gorley RN (2001) Primer Version 5. Primer-E, Plymouth

Clarke KR, Warwick RM (2001) Change in marine communities: an approach to statistical analysis and interpretation, 2nd ed. Primer-E, Plymouth

Coleman MA (2003) Effects of ephemeral algae on coralline recruits in intertidal and subtidal habitats. J Exp Mar Biol Ecol 282:67-84

Connell JH (1972) Community interactions on marine rocky intertidal shores. Ann Rev Ecol Syst 3:169-192

Connell JH (1978) Diversity in tropical rain forests and coral reefs. Science 199:1302-1309

Connell JH, Slayter RO (1977) Mechanisms of succession in natural communities and their role in community stability and organization. Am Nat 111:1119-1144

Dayton PK (1975) Experimental evaluation of ecological dom- inance in a rocky intertidal algal community. Ecol Monogr 45:137-159

Farrell TM (1989) Succession in a rocky intertidal community: the importance of disturbance size and position within a disturbed patch. J Exp Mar Biol Ecol 128:57-73

Farrell TM (1991) Models and mechanisms of succession: an example from a rocky intertidal community. Ecol Monogr 6:95-113

Figueiredo MA, Kain JM, Norton TM (2000) Responses of crustose corallines to epiphyte and canopy cover. J Phycol $36: 17-24$

Foster MS, Nigg EW, Kiguchi LM, Hardin DD, Pearse JS (2003) Temporal variation and succession in an algaldominated high intertidal assemblage. J Exp Mar Biol Ecol 289:15-39

Jenkins SR, Hawkins SJ, Norton TA (1999a) Direct and indirect effects of a macroalgal canopy and limpet grazing in structuring a sheltered inter-tidal community. Mar Ecol Prog Ser 188:81-92

Jenkins SR, Hawkins SJ, Norton TA (1999b) Interaction between a fucoid canopy and limpet grazing in structuring a low shore intertidal community. J Exp Mar Biol Ecol 233:41-63

Jenkins SR, Norton TA, Hawkins SJ (2004) Long term effects of Ascophyllum nodosum canopy removal on mid shore community structure. J Mar Biol Assoc UK 84:327-329

Johst K, Huth A (2005) Testing the intermediate disturbance hypothesis: When will there be two peaks of diversity? Divers Distrib 11:111-120

Kennelly SJ (1987) Physical disturbances in an Australian kelp community. II. Effects of understory species due to differences in kelp cover. Mar Ecol Prog Ser 40:155-165

Kim JH, DeWreede RE (1996) Effects of size and season of disturbance on algal patch recovery in a rocky intertidal community. Mar Ecol Prog Ser 133:217-228

Lilley SA, Schiel DR (2006) Community effects following the deletion of a habitat-forming alga from rocky marine shores. Oecologia 148:672-681

Lubchenco J, Menge BA (1978) Community development and persistence in a low rocky intertidal zone. Ecol Monogr 48:67-94

Melville AJ, Connell SD (2001) Experimental effects of kelp canopies on subtidal coralline algae. Austral Ecol 26:102-108

Paine RT (1985) Perturbation and recovery patterns of starfish-dominated intertidal assemblage in Chile, New Zealand and Washington state. Am Nat 125:679-691

Ramage DL, Schiel DR (1999) Patch dynamics and response to disturbance of the seagrass Zostera novazelandica on intertidal platforms in southern New Zealand. Mar Ecol Prog Ser 189:275-288

Schiel DR (2004) The structure and replenishment of rocky shore intertidal communities and biogeographic comparisons. J Exp Mar Biol Ecol 300:309-342

Schiel DR (2006) Rivets or bolts? When single species count in the function of temperate rocky reef communities. J Exp Mar Biol Ecol 8:233-252

Schiel DR, Taylor DI (1999) Effects of trampling on a rocky intertidal algal assemblage in southern New Zealand. J Exp Mar Biol Ecol 235:213-235

Schiel DR, Wood SA, Dunmore RA, Taylor DI (2006) Sediment on rocky intertidal reefs: effects on early post-settlement stages of habitat-forming seaweeds. J Exp Mar Biol Ecol 331:158-172

Seed R (1996) Patterns of biodiversity in the macro-invertebrate fauna associated with mussel patches on rocky shores. J Mar Biol Assoc UK 76:203-210

Shea K, Roxburgh SH, Rauschert SJ (2004) Moving from 
pattern to process: coexistence mechanism under intermediate disturbance regimes. Trends Ecol Evol 7:491-508

Sousa WP (1979) Disturbance in marine intertidal boulder fields: the nonequilibrium maintenance of species diversity. Ecology 60:1225-1239

Speidel M, Harley CDG, Wonham MJ (2001) Recovery of the brown alga Fucus gardneri following a range of removal intensities. Aquat Bot 71:273-280

Stimson J (1985) The effect of shading by the table coral Acropora hyacinthus on understorey corals. Ecology 66:40-53

Strauss SY (1991) Indirect effects in community ecology: their definition, study and importance. Trends Ecol Evol 6: 206-210

Underwood AJ (1998) Grazing and disturbance: an experimental analysis of patchiness in recovery from a severe storm by the intertidal alga Hormosira banksii on rocky shores in New South Wales. J Exp Mar Biol Ecol 231:291-306

Underwood AJ (1999) Physical disturbances and their direct effect on an indirect effect: responses of an intertidal assemblage to a severe storm. J Exp Mar Biol Ecol 232: $125-140$

Appendix 1. List of macroscopic benthic understory taxa found at Mudstone Bay (MB) and Wairepo Flats (WF) throughout the duration of the experiment. ${ }^{*}$ Denotes presence of taxa

\begin{tabular}{|c|c|c|c|c|c|}
\hline & MB & WF & & MB & WF \\
\hline \multicolumn{6}{|l|}{ Perennial algae } \\
\hline Fucoids & & & Molluscan grazers & & \\
\hline Carpophyllum maschalocarpum & * & * & Cantharidella tesselata & * & * \\
\hline Cystophora retroflexa & * & & Chiton glaucus & $*$ & * \\
\hline Cystophora scalaris & * & ${ }^{*}$ & Chiton pelliserpentis & * & * \\
\hline Cystophora torulosa & * & * & Maorichiton caelatus & * & * \\
\hline Hormosira banksii & ${ }^{*}$ & ${ }^{*}$ & Margarella spp. & * & * \\
\hline Coralline turfing algae & & & Melagraphia aethiops & ${ }^{*}$ & * \\
\hline Corallina officinalis & * & * & Notoacmea spp. & & * \\
\hline Haliptilon roseum & & * & Risellopsis varia & & * \\
\hline Jania micrarthrodia & * & & Siphonaria spp. & ${ }^{*}$ & * \\
\hline $\begin{array}{l}\text { Jania sp. } \\
\text { Other algae }\end{array}$ & * & * & Turbo smaragdus & * & * \\
\hline $\begin{array}{l}\text { Other algae } \\
\text { Echinothamnion sp. }\end{array}$ & * & * & Zeacumantus spp. & * & $*$ \\
\hline Encrusting algae & * & & Anemones & & \\
\hline Gelidium caulacantheum & * & * & Actinia tenebrosa & * & \\
\hline Halopteris spp. & * & * & Actinothoe albens & * & * \\
\hline Laurencia thyrsifera & * & * & Anthopleura spp. & * & * \\
\hline Non-geniculate corallines & * & * & Cricophorus nutrix & * & * \\
\hline Notheia anomala & * & * & Epiactis thompsoni & * & \\
\hline Ephemeral algae & & & Isactinia olivacea & * & * \\
\hline Adenocystis utricularis & * & ${ }^{*}$ & Other & & \\
\hline Blue-green algae & * & * & Aulacomya maoriana (Bivalvia) & & * \\
\hline Bryocladia ericoides & * & & Buccinulum spp. (Gastropoda) & * & * \\
\hline Bryopsis vestia & * & & Cancer novaezelandiae & * & \\
\hline Centrocerus spp. & * & $*$ & Chamaesipho columna (Cirripedia) & & \\
\hline $\begin{array}{l}\text { Ceramium spp. } \\
\text { Chaetomorpha aerea }\end{array}$ & * & 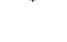 & Cominella glandiformis (Gastropoda) & & * \\
\hline $\begin{array}{l}\text { Chaetomorpha aerea } \\
\text { Chaetomorpha coliformis }\end{array}$ & * & * & Cominella maculosa (Gastropoda) & * & * \\
\hline $\begin{array}{l}\text { Chaetomorpha coliformis } \\
\text { Chaetomorpha valida }\end{array}$ & * & & Halicarcinus spp. (Decapoda) & * & * \\
\hline Champia novae-zealandiae & * & * & Haustrum haustorium (Gastropoda) & $*$ & * \\
\hline Codium convalutum & * & & Mytilus galloprovincialis (Bivalvia) & & * \\
\hline Colpomenia sinuosa & * & * & Nereidae & * & * \\
\hline Dictyota spp. & ${ }^{*}$ & * & Ophionereis fasciata (Echinodermata) & * & * \\
\hline Dipterosiphonia heteroclada & * & & Opisthobranchs & * & * \\
\hline Ectocarpus spp. & * & * & Patiriella regularis (Echinodermata) & & * \\
\hline Enteromorpha bulbosa & * & * & Sabellariidae & * & \\
\hline Gigartina chapmanii & * & & Serpulidae & * & * \\
\hline Hymenena sp. & * & ${ }^{*}$ & Sphaeromatidae (Isopoda) & * & * \\
\hline Leathesia difformis & * & * & Terebellidae & * & * \\
\hline Lophurella caespitosa & * & & UID Sponge & * & * \\
\hline Petalonia fasciata & ${ }^{*}$ & & UID Whelk A & * & * \\
\hline Pleonosporium hirtum & * & * & Valvifera (Isopoda) & * & \\
\hline Polysiphonia spp. & $*$ & & & & \\
\hline Scytosiphon lomentaria & ${ }_{*}^{*}$ & * & & & \\
\hline $\begin{array}{l}\text { UID Red Filament } \\
\text { Ulva spp. }\end{array}$ & * & * & & & \\
\hline
\end{tabular}

Editorial responsibility: Howard Browman (Associate Editorin-Chief), Storebø, Norway
Submitted: March 23, 2006; Accepted: May 6, 2007

Proofs received from author(s): May 21, 2007 